\title{
Production of propionic acid
}

\author{
P Boyaval, C Corre \\ Laboratoire de recherches de technologie laitière, INRA, 65, rue de Saint-Brieuc, \\ 35042 Rennes cedex, France
}

\begin{abstract}
Summary - Propionic acid and its salts are widely used in industry and especially in the food industry as antifungal agents. The estimated world production in 1992 was about 100000 tonnes. A large part of this production is by petrochemical routes. Nevertheless, fermentation processes have been described since 1923. The increasing consumer demand for biological products and the more efficient performance of new fermentation processes have revived researcher and industrial interest for a new investigation of biological propionic acid production. From the low productivity of batch processes $\left(0.03 \mathrm{~g} \mathrm{t}^{-1} \mathrm{~h}^{-1}\right)$, performance has rapidly increased to 2 to $14 \mathrm{gl}^{-1} \mathrm{~h}^{-1}$. This increase results from the emergence of high density cell bioreactor technology. These bioreactors make it possible to concentrate large amounts of cells within the system during continuous fermentation and to reduce the cell inhibition effect of organic acid accumulation in the medium. Moreover, the use of glycerol as the principal carbon source enables propionic acid to be produced without acetic acid. The increased efficiency of membrane processes, such as electro-electrodialysis and electrodialysis with bipolar membrane, has considerably facilitated the recovery and purification steps from fermented media. The increased fermentation volumetric productivity and downstream processing performance has led to an economic industrial biological propionic acid production.
\end{abstract}

\section{propionic acid / bioreactor / purification / glycerol / Propionibacterium}

Résumé - La production d'acide propionique. L'acide propionique et les sels d'acide propionique sont très largement utilisés dans l'industrie, et notamment dans les industries agro-alimentaires, pour leur rôle antifongique. La production mondiale estimée en 1992 était de 100000 tonnes. Une très large proportion de cet acide est fabriquée par voie chimique, à l'aide de différents procédés issus de l'industrie pétrolière. Néanmoins, des procédés de fermentations sont décrits depuis 1923. L'intérêt croissant des consommateurs pour des produits naturels et l'émergence de techniques de fermentation de plus en plus performantes ont renouvelé l'intérêt des chercheurs et des industriels pour une production biologique d'acide propionique. De très faibles productivités volumiques $\left(0,03 \mathrm{~g}^{-1} \mathrm{~h}^{-1}\right)$ pour les procédés batch, les résultats ont rapidement atteint de 2 à $14 \mathrm{~g} \mathrm{t}^{-1} \mathrm{~h}^{-1}$. Cette augmentation est principalement le fruit de l'introduction de la technologie des bioréacteurs à recyclage cellulaire qui permettent d'augmenter la biomasse au sein du système et de lever l'inhibition provoquée par l'accumulation d'acides dans le milieu de fermentation. L'introduction du glycérol en tant que principale source carbonée a conduit à l'obtention d'acide propionique sans la présence d'acide acétique. De plus, l'introduction de techniques de séparation performantes (électro-électrodialyse et électrodialyse à membranes bipo- 
laires) a considérablement facilité la récupération et la purification de l'acide propionique à partir de moûts de fermentation. La combinaison de ces différentes améliorations conduit actuellement à une industrie de production d'acide propionique par fermentation économiquement performante.

acide propionique / bioréacteur / purification / glycerol / Propionibacterium

\section{INTRODUCTION}

Propionic acid and its salts are used in numerous processes such as in the production of cellulose plastics (used in textiles, filters, reverse osmosis membranes, lacquer formulations and moulding plastics), herbicides, in the manufacture of ester solvents, fruit flavours (citronellyl propionate and geranyl propionate), perfume bases and butyl rubber to improve processability and scorching resistance. In animal therapy, sodium propionate has been used in dermatoses, wound infections, anti-arthritic drugs and conjunctivitis. In the food industry, propionic acid (E 280) and its sodium ( $E$ 281), calcium (E 282) and potassium salts (E 283) are incorporated to suppress the growth of mould and rope in breads and cakes, on the surface of cheeses, meats, fruits, vegetables, and tobacco, grain and silage preservation, and to prevent the blowing of canned frankfurters without affecting their flavour. Dipping containers, caps and wrappers in solutions of these salts is also effective. Moreover, the association of propionic acid with lactic and acetic acids has been recommended for the preservation of foods. This recommendation was reinforced by the works which demonstrated the synergistic effect of these acids on the inhibition of Listeria monocytogenes growth in foods. The Food and Drug Administration (FDA) lists the acid, the $\mathrm{Na}^{+}, \mathrm{Ca}^{++}$and $\mathrm{K}^{+}$salts as preservatives in their summary of Generally Recognized As Safe (GRAS) additives and no upper limits are imposed, except for bread, rolls and cheeses ( 0.30 to $0.38 \%$ ). Propionate is metabolized like other fatty acids in the mammalian body.

\section{MARKET SIZE AND COST}

Reliable statistics on production of the acid plant capacities and price trends are not available for many countries which export propionic acid (China, etc). The main producers are American (Union Carbide, Eastman and Celanese). In 1982, their production was 50000 tonnes annually for a plant capacity of 107000 tonnes. The current estimations are 60000 tonnes per year in the United States and 40000 tonnes in Western Europe. The cost has increased from US $\$ 0.73 \mathrm{~kg}^{-1}$ (1982) to US $\$ 1 \mathrm{~kg}^{-1}$ (1992).

\section{PROPIONIC ACID PRODUCTION PROCESSES}

\section{Chemical processes}

Several processes exist for the production of propionic acid. These include the Reppe process from ethylene, carbon monoxide and steam, and the Larson process from ethanol and carbon monoxide using boron trifluoride as a catalyst. The acid is also obtained by oxidation of propionaldehyde, as a by-product in the Fischer-Tropsch process for the synthesis of fuel and in wood distillation as a by-product of the pyrolysis. Very pure propionic acid can be obtained from propionitrile.

Fewer supplies and the higher cost of oil, the opportunity to use by-products of the food industry as inexpensive media, the increasing consumer demand for organic 
natural products and the emergence of more efficient fermentation processes have led to a new opportunity for microbial production to be economically attractive.

\section{Fermentation processes}

\section{Microbiology of the fermentations}

The first works on propionic acid fermentation resulted in the formulation of the Fitz equation:

3 lactic acid $\longrightarrow 2$ propionic acid +1 acetic acid $+1 \mathrm{CO}_{2}+1 \mathrm{H}_{2} \mathrm{O}$

or

1.5 glucose $\rightarrow 2$ propionic acid +1 acetic acid $+1 \mathrm{CO}_{2}+1 \mathrm{H}_{2} \mathrm{O}$

Theoretical maximum yields are $54.8 \%$ $(w / w)$ as propionic acid and $77 \%$ as total acids. Formation of propionic acid is accompanied by the formation of acetate for stoichiometric reasons and to maintain hydrogen and redox balances. The dicarboxylic acid pathway is the most common pathway for the formation of propionic acid. The acrylic pathway, restricted to a few species of bacteria (Clostridium propionicum, Megasphaera elsdenii, Bacteroides ruminicola), also leads to propionic acid formation.

\section{The processes: state of the art}

Today, the industrial production of propionic acid is almost entirely by petrochemical routes, although numerous fermentation processes have been patented since 1923 , mainly with strains of the Propionibacterium genus. They have never passed the pilot plant level because: (i) propionic acid fermentation is a very fastidious task ( 1 to 2 weeks to be completed in batch); (ii) the production of organic acids by Propionibacterium is end-product-inhibited by acetic and propionic acids; and (iii) separation and concentration of the acid is expensive (low concentration, small difference of volatility between acid and water, and presence of other acids, especially acetic acid).

Nevertheless, a lot of work has been done to establish the most important characteristics of the production of propionic acid by fermentation with propionic acid bacteria. Playne (1985) reported more than 40 patents resulting in increased productivity, inexpensive media (wood pulp waste liquor, steep water, maize gluten, whey, starch hydrolysates, sulphite waste liquors, lignocellulose, etc) or more efficient recovery. Propionibacterium were also grown in mixed cultures with lactic acid bacteria. They have been immobilized in calcium-alginate beads, in polyacrylamide gels and in membrane bioreactors.

The recent improvements in fermentation technology, with the introduction of high cell density bioreactors, the enhancement of recovery efficiency of membrane processes and the increasing demand of consumers for biological products, have led the Laboratory of Dairy Technology Research of INRA (Rennes, France) to a systematic investigation of the improvement of propionic acid fermentation.

\section{Enhancement of propionic acid produc- tivity of fermentation processes}

\section{Process improvement}

Propionibacterium acidi propionici was used to ferment lactose from whey permeate to propionic acid in a continuous stirred tank reactor with cell recycle (fig 1 ). The cells were separated from the medium and recycled back to the bioreactor using an ultrafiltration unit. This fermentation system makes it possible to reduce the propionic acid inhibitory effect on the cells, to increase the concentration of viable microbes in the biore- 
actor and consequently to obtain higher volumetric productivity than the conventional method. If batch fermentation realized volumetric productivity of $0.03 \mathrm{~g} \mathrm{I}^{-1} \mathrm{~h}^{-1}$, this membrane bioreactor attained a productivity of $14.3 \mathrm{~g} \mathrm{l}^{-1} \mathrm{~h}^{-1}$ : more than 480 times greater than the traditional process (Boyaval and Corre, 1987). As already observed during lactic acid production, the specific acid productivity decreased when the biomass increased in the bioreactor: from $0.4 \mathrm{~g}$ of propionic acid per gram of cells per hour $\left(\mathrm{g} \mathrm{l}^{-1} \mathrm{~h}^{-1}\right)$ at $10 \mathrm{gl}^{-1}$ to $0.17 \mathrm{~g} \mathrm{~g}^{-1} \mathrm{~h}^{-1}$ at $80 \mathrm{~g}$ $1^{-1}$. This decreased cell specific productivity at high cell concentration was probably the result of physiological perturbations (inhibition, substrate limitation or variations in the intracellular water content of the cells, etc).

The acid concentration was $25 \mathrm{~g} \mathrm{I}^{-1}$ and the biomass reached $100 \mathrm{~g} \mathrm{l}^{-1}$ (dry weight [DW]). A periodic bleeding of this concentrated biomass, used to keep a high cell specific productivity, could be an interesting source of propionic acid bacteria starters, which play an important role in the ripening of Swiss-type cheeses. Table I presents the productivity of the principal types of fermentation processes for propionic acid production. These results, obtained with a CSTR with ultrafiltration recycle, led to a pilot plant and an industrial plant $\left(37 \mathrm{~m}^{3}\right)$ coupled with $32 \mathrm{~m}^{2}$ of ceramic membranes (Boyaval et al, 1991). The continuous pro-

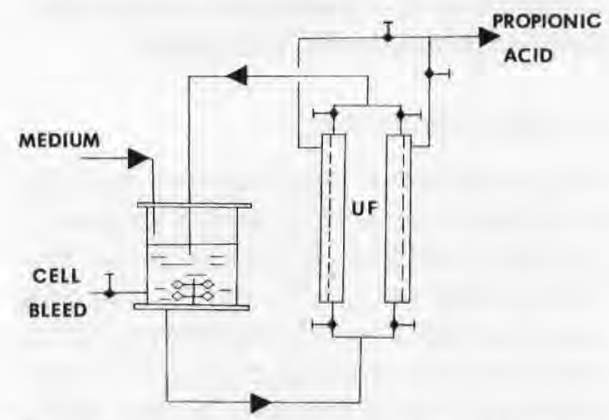

Fig 1. Schematic flow sheet diagram of the process. (UF: ultrafiltration unit).

Schéma simplifié du procédé. cess was converted to a sequential one (Colomban et al, 1993).

The sequential mode of operation offered several advantages. The technical operations were very similar to batch fermentation, therefore the process was rapidly assimilated by the staff. This programme allows utilization of only 1 membrane device for several bioreactors, which is very useful from an economic point of view. The time for filtration was shorter compared to the continuous use of a membrane bioreactor. There was less clogging of the membrane, so the permeate flux was higher and the cleaning procedures were less involved. In addition, this membrane filter can be washed during fermentation, a step impossible to achieve in continuous runs except if the bioreactor is coupled to 2 units, 1 being used for filtration while the other is being washed (however, 2 pumps are used in this case). Finally, the filtration device can be employed to sterilize the medium before fermentation between normal operating steps.

Nevertheless, only a few studies have dealt with that type of operation. Semicontinuous processes have been used to improve the yield of propionic acid in a conventional bioreactor. Repeated recycling culture has been tested previously by Lee and Chang (1990) to alleviate the acetic acid inhibition in $E$ coli and by Denis and Boyaval (1991) to produce an extracellular microbial enzyme in a membrane bioreactor. This mode of bioreactor operation will probably be more appreciated by professionals for industrial fermentation plants than the continuous fermentation because it is easier to set up in the factory.

The long-term stability of the process has been proved with the runs presented here $(1000 \mathrm{~h})$ and with numerous others. We have observed no loss of catalytic activity of our strains. Moreover, it seems possible to increase the resistance of $P$ acidi-propionici to organic acid inhibition by long, peri- 
Table I. Comparison of propionic acid fermentation processes.

Comparaison des procédés de fermentation pour la production d'acide propionique.

\begin{tabular}{|c|c|c|c|c|c|c|}
\hline Organism & System & $\begin{array}{l}\text { Carbon } \\
\text { source }\end{array}$ & $\begin{array}{c}\text { Cell } \\
\text { concentration } \\
\left(g \vdash^{-1}\right)\end{array}$ & $\begin{array}{c}\text { Propionic } \\
\text { acid } \\
\text { concentration } \\
\left(g \vdash^{-1}\right)\end{array}$ & $\begin{array}{c}\text { Volumetric } \\
\text { productivity } \\
\left(\mathrm{g}^{-1} \mathrm{~h}^{-1}\right)\end{array}$ & Reference \\
\hline$P$ acidi-propionici & Batch & $\begin{array}{l}\text { Lactose } \\
\text { Glucose }\end{array}$ & - & 2.37 & 0.033 & $\begin{array}{c}\text { Sherman \& Shaw } \\
\text { (1923) }\end{array}$ \\
\hline \multirow[t]{2}{*}{$\begin{array}{l}\text { P acidi-propionici } \\
\text { (ATCC 25562) }\end{array}$} & CSTR & $\begin{array}{l}\text { Glucose } \\
\text { Xylose }\end{array}$ & $\begin{array}{c}1.510^{9} 9.510^{11} \\
\text { cells ml-1 }\end{array}$ & 3.74 & $\begin{array}{l}0.19 \\
0.18\end{array}$ & \\
\hline & $\begin{array}{l}\text { Plug flow } \\
\text { tubular } \\
\text { reactor }\end{array}$ & $\begin{array}{l}\text { Glycose } \\
\text { Xylose }\end{array}$ & - & - & $\begin{array}{l}0.49 \\
0.40\end{array}$ & $\begin{array}{c}\text { Clausen \& Gaddy } \\
\text { (1984) }\end{array}$ \\
\hline Propionibacterium $\mathrm{sp}$ & $\begin{array}{l}\text { Calcium } \\
\text { alginate } \\
\text { gel beads }\end{array}$ & Na-lactate & $\begin{array}{l}410^{9} \text { cells } \\
\text { (free) } \mathrm{ml}^{-4}\end{array}$ & 5 & 2 & $\begin{array}{c}\text { Cavin et al } \\
\text { (1989) }\end{array}$ \\
\hline $\begin{array}{l}\text { P acidi-propionici } \\
\text { (ATCC 25562) }\end{array}$ & $\begin{array}{l}\text { CSTR + UF } \\
\text { cell recycle }\end{array}$ & Xylose & 95 & 18 & 2.2 & $\begin{array}{c}\text { Carrondo et al } \\
\quad(1987)\end{array}$ \\
\hline$P$ acidi-propionici & $\begin{array}{l}\text { CSTR + UF } \\
\text { cell recycle }\end{array}$ & Lactose & 100 & 25 & 14.3 & $\begin{array}{c}\text { Boyaval \& Corre } \\
(1987)\end{array}$ \\
\hline
\end{tabular}

odic cultures with medium enriched in propionic and acetic acids.

At present, trials are performed with $30 \%$ dry matter (220 $\mathrm{g} \mathrm{I}^{-1}$ lactose) in order to achieve higher propionic acid contents and to increase the propionic/acetic acid ratio. These runs are conducted with a higher biomass content $\left(>80 \mathrm{~g} \mathrm{l}^{-1}\right)$. The aim of these experiments is to find a balance between an increased propionic acid concentration and the decreased specific productivity due to the higher biomass and acid contents of the medium, without neglecting a total lactose consumption.

Even though propionic and acetic acids are the 2 major end products of lactose fermentation by propionic acid bacteria, other acids could be produced in the medium: lac- tic, succinic, pyruvic, malic, fumaric, isovaleric and formic acids. These "by-products" must be carefully examined because variations in the process and especially in the growth medium and agitation speed lead to important variations in the concentration of these products. A decreased yield of propionic acid production and a modification of the final product of the fermentation are then observed.

Moreover, the recent work of $\mathrm{Hsu}$ and Yang (1991) shows that even if neutral $\mathrm{pH}$ is optimum for the growth of Propionibacterium acidi-propionici, the propionic acid yield is low. On the other hand, in the acidic $\mathrm{pH}$ range, the growth rate is low but the yield is double. With our particular mode of operation, it will be easy to multiply the cells, in 
the first cycles, at a neutral $\mathrm{pH}$ and to allow an acidification for the next ones to enhance the yield. A safer process will be obtained at this lower $\mathrm{pH}$. This process makes it possible to produce concentrated cells $\left(200 \mathrm{~g} \mathrm{I}^{-1}\right.$ DW) which can be used as cheese starters in the factory.

\section{Propionic acid production with glycerol as carbon source}

Until now, all of the carbon sources used to produce propionic acid by fermentation have led to the cosynthesis of acetic acid. Using Propionibacterium thoenii NCDO 1082, we demonstrated that fermentation of glycerol by this propionic acid bacteria led only to propionic acid with no acetic acid. Fed-batch experiments were performed (fig 2). The highest productivity was $0.3 \mathrm{~g} \mathrm{l}^{-1} \mathrm{~h}^{-1}$, and the maximum concentration was $40 \pm 2 \mathrm{~g} \mathrm{l}^{-1}$. The specific acid production rate was equal to zero when the acid concentration reached this value. Continuous fermentation with a membrane bioreactor realized the production of highquality propionic acid with a volumetric productivity of $1 \mathrm{~g} \mathrm{l}^{-1} \mathrm{~h}^{-1}$ (Boyaval et al, 1994). The process can be conducted with a complete medium with glycerol as the carbon source or with glycerol only during "production steps", while a complete medium can be used periodically to "regenerate" the production potential of the cells visualized by a decreasing specific acid productivity. As a result, the fermented medium does not show any components issuing from yeast extract or other nitrogen compounds. This greatly simplifies the downstream processing for that product. For example, direct electro-electrodialysis (EED) or electrodialysis (ED) with bipolar membranes will be successfully used to concentrate the propionate salt and to convert it to the acid form. Clogging of the membranes, which is the main problem of this type of technology, will be greatly reduced.
Glycerol has now become an inexpensive carbon source. The new processes used to extract fuel from vegetable oils produce a large quantity of glycerol as a byproduct which needs new uses. The increasing interest in a natural source of propionic acid highlights the great demand of this biosynthesis for industrial processes that need high-quality acid.

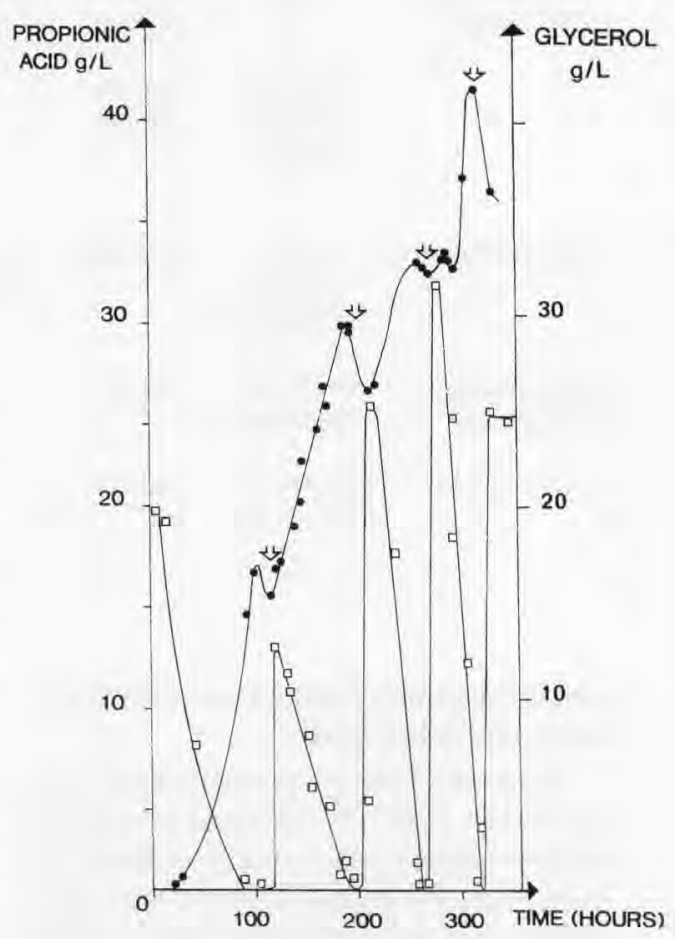

Fig 2. Typical fed-batch experiment. Four additions of pure glycerol of indicated by arrows on the figure $15,30,40$ and $30 \mathrm{ml}$ were done during this run. Initial volume $1.21 ; \mathrm{pH} 6.8$; temperature $30^{\circ} \mathrm{C}$. (๑) Propionic acid; (Ј) glycerol.

Résultat d'une expérience de fed-batch. Quatre additions de glycérol pur de 15, 30,40 et $30 \mathrm{ml}$ ont été réalisées au cours de cette fermentation. Le volume initial était de $1,2 \mathrm{l}$, le $\mathrm{pH} 6,8$ et la température $30^{\circ} \mathrm{C}$. (•) Acide propionique; (घ) glycérol. 


\section{PROPIONIC ACID RECOVERY AND PURIFICATION}

\section{State of the art}

Downstream processing of organic acids from fermentation is often the major financial drawback of the process. This is also true for the recovery of propionic acid. This acid is highly hydrophilic and the difference of volatility between propionic acid and water is small. Moreover, the optimum $\mathrm{pH}$ range for that fermentation is, like many other acidogenic fermentations, between 6.0 and 7.0. This means that the acid is in the ionized state and hence is completely nonvolatile. The acid concentration is generally, for fermentation processes, less than 50 $\mathrm{gl}^{-1}$. This low concentrated product, among many other molecules present in the fermentation broth, embarrasses the purification. The main purification processes employed today are: acidification of the fermentation media followed by recovery with anion exchange resins; solvent extraction and distillation; salting out procedures; esterification of the acid with ethanol or butanol (the ester is less soluble in water); membrane techniques; and other techniques such as supercritical fluid extraction and adsorption on zeolite (others have been examined but, to our knowledge, are not largely employed).

\section{Enhancement of downstream processing efficiency}

As for other organic acids, the $\mathrm{pH}$ must be maintained during fermentation in order to increase the productivity. Then salts such as sodium or calcium propionate are obtained. For numerous uses, however, the acid form is required. Thus, it was interesting to convert easily and economically propionate salts to propionic acid, with a con- comitant concentration of the product. ED with bipolar membranes (BPM: water-splitting at the junction of 2 homopolar membranes) and EED enable inorganic and organic anions to be extracted and combined with protons to produce acids (fig 3 ).

The evolution of time of propionic acid concentration from the solution (fig 4) is characteristic of the extraction-reconcentration curve obtained by ED. In the concentrate, the amount of the extracted electrolyte first increases linearly before reaching the reconcentration plateau. This reconcentration level is limited by the ion leakage through the membrane and the water transport. The results recorded here suggest that the limiting process is the water transport through the anion exchange membrane. Moreover, in the presence of only propionic acid, the water transport through the BPM has the same effect as the water consumption taking place during the EED experiment and resulting from the water electrolysis at the anode.

The results show that the acetate and lactate ions, which are present with propionate ions in the fermentation broth, are extracted at the same time, giving rise to the production of acetic and lactic acid in compartment 2 . In the 2 processes, after $25 \mathrm{~h}$, the propionic acid concentration increases again with time. This result may be explained by the fact that the totality of acetate and lactate ions having been extracted from the fermentation broth, only the propionate ion is carried through the anion exchange membrane and the efficiency of the electrotransport of propionate becomes higher. Therefore, the amount of propionic acid will most likely be increased, leading to a more concentrated propionic acid, with longer experiments.

Concentrated propionic acid was obtained by EED and ED with bipolar membranes of the fermentation broth. The current efficiency was high but decreased with time, especially with bipolar membranes. The 


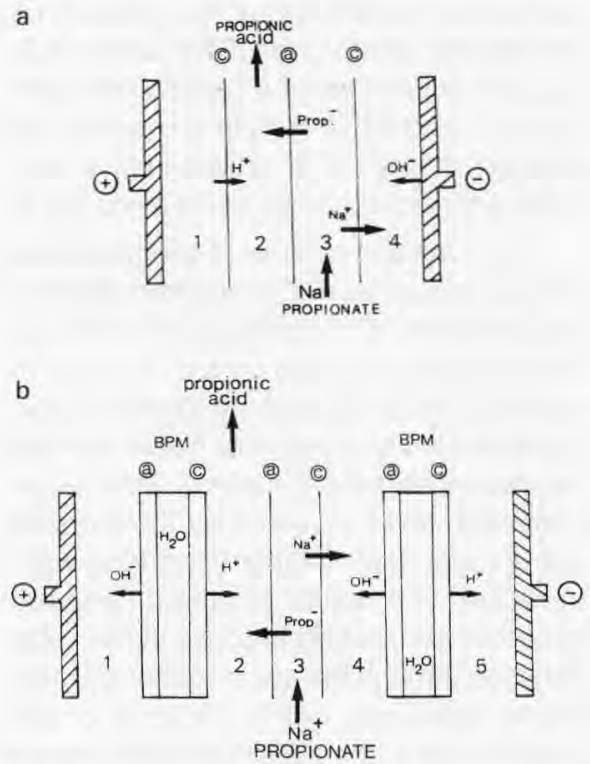

Fig 3a. Laboratory cell device for electro-electrodialysis. $\mathrm{c}=$ Cation exchange membrane; $\mathrm{a}=$ anion exchange membrane. b. Laboratory cell device for electrodialyser with bipolar membranes (BPM).

a. Équipement de laboratoire pour l'électro-électrodialyse (EED). $c=$ membrane échangeuse de cations ; $a$ = membrane échangeuse d'anions. b. Équipement de laboratoire pour l'électrodialyse (ED) avec des membranes bipolaires.

presence of inorganic ions led to the formation of other acids (Boyaval et al, 1993).

The influence of the water transport as well as the current density need to be analysed more thoroughly, taking into consideration the electrical energy consumption of these processes in order to obtain data which are necessary for economic estimations.

In an extractive fermentation process, EED and ED with bipolar membranes can be used to decrease the acid level in the medium and then allow high cell multiplication and fast acid production. Moreover, the sodium hydroxide produced can be easily employed for the $\mathrm{pH}$ control of the bioreac-

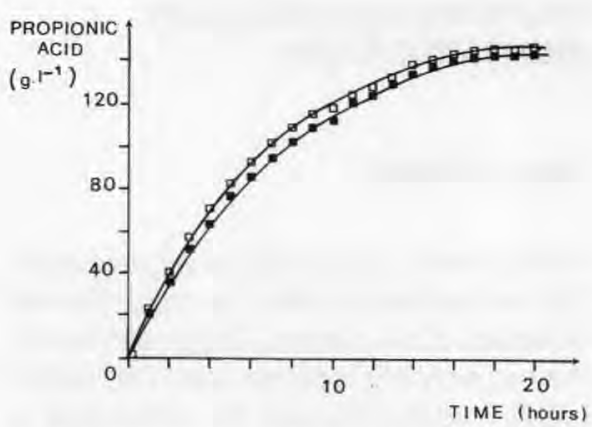

Fig 4. Electro-electrodialysis (EED) and electrodialysis (ED) with bipolar membrane of a solution of propionic acid $\left(40 \mathrm{gl}^{-1}\right)$.Variation with time of the concentration of propionic acid in the compartment 2: ( $\sqsupset$ ) EED, (四) ED with bipolar membranes (BPM). Current density $70 \mathrm{~mA} \mathrm{~cm}^{-2}$.

Électro-électrodialyse (EED) et électrodialyse (ED) avec des membranes bipolaires d'une solution d'acide propionique à $40 \mathrm{~g} \mathrm{t}^{-1}$. Évolution de la concentration de l'acide propionique en fonction du temps dans le compartiment 2: (]) EED, (回) $E D$ avec des membranes bipolaires. Densité de courant $70 \mathrm{~mA} \mathrm{~cm}^{-2}$.

tor. Compared with solvent extraction, the membrane processes described assume no trace of extractive solvent in the product with the subsequent problems to food acceptability; no problem of pollution by chemical release and associated sodium hydroxide production which can be re-used in the fermentation process. Previous ultrafiltration of the fermented whey UF permeate achieved in continuous fermentations with membrane bioreactors permits in line use of this sophisticated technology without clogging problems.

\section{CONCLUSION}

At present, continuous stirred tank reactor coupled with ultrafiltration cell recycle may prove to be the most appropriate process for propionic acid production. Nanofiltration membranes have been used to show the feasi- 
bility of the production of highly pure propionic acid with no residual lactose. In addition, the biological propionic acid colour was greatly reduced. The performance obtained with a bioreactor coupled to nanofiltration membrane for lactic acid production is very promising for the production of propionic acid.

The complete overview of the performances of EED and the use of bipolar membranes for the recovery and concentration of propionic acid (or other organic acids obtained by fermentation processes) need a serious examination of different parameters (membrane nature, current density) and an economic evaluation of the process is essential.

\section{REFERENCES}

Boyaval P, Corre C (1987) Continuous fermentation of sweet whey permeate for propionic acid production in a CSTR with UF recycle. Biotechnol Lett 9, 801-806

Boyaval P, Colomban A, Roger L (1991) Semi-continuous fermentation process for the production of biological propionic acid based preparations. European Patent $n^{\circ} 9146002206$

Boyaval P, Seta J, Gavach C (1993) Concentrated propionic acid production by electrodialysis. Enzyme Microb Technol 15, 683-686
Boyaval P, Corre C, Madec M-N (1994) Propionic acid production in a membrane bioreactor. Enzyme Microb Technol 16, 883-886

Colomban A, Roger L, Boyaval P (1993) Production of propionic acid from whey permeate by sequential fermentation, ultrafiltration, and cell recycling. Biotechnol Bioeng 42, 1091-1098

Carrondo MJT, Crespo JPSG, Moura MJ (1988) Production of propionic acid using a xylose utilizing Propionibacterium. Appl Biochem Biotechnol 17, 295312

Cavin JF, Saint C, Divies C (1985) Continuous production of Emmental cheese flavours and propionic acid starters by immobilized cells of a propionic acid bacterium. Biotechnol Lett 7, 821-826

Clausen EC, Gaddy JL (1984) Organic acids from biomass by continuous fermentation. Chem Eng Prog 80, 59-63

Denis S, Boyaval P (1991) Microbial enzyme production in a membrane bioreactor. Appl Microbiol Biotechnol 34, 608-612

Hsu ST, Yang ST (1991) Propionic acid fermentation of lactose by Propionibacterium acidipropionici: effects of $\mathrm{pH}$. Biotechnol Bioeng 38, 571-578

Lee YL, Chang HN (1990) High cell density culture of a recombinant Escherichia coli producing penicillin acylase in a membrane cell recycle fermentor. Biotechnol Bioeng 36, 330-337

Playne MJ (1985) Propionic and butyric acids. In: Comprehensive Biotechnology, Vol 3 (M Moo-Young, ed) Pergamon Press, Oxford, UK, 731-759

Sherman JM, Shaw RH (1943) The propionic acid fermentation of lactose. J Biol Chem $56,695-700$ 